\title{
The Present Fisheries Status of Assam: A Review
}

\author{
Rajesh Debnath $^{1}$, Gora Shiva Prasad ${ }^{1 *}$, Abdul Aziz ${ }^{1}$, Kovvuri Chalapathi ${ }^{2}$, \\ Ranga Ram Mohan ${ }^{2}$, Satarupa Ghosh ${ }^{1}$ and Abhishek Kumar ${ }^{1}$ \\ ${ }^{1}$ Faculty of Fishery Science, WBUAFS, Kolkata- 700094, West Bengal, India \\ ${ }^{2}$ College of Fishery Sciences, SVVU, Muthukur-524344, Andhra Pradesh, India \\ *Corresponding author
}

\section{A B S T R A C T}

\begin{tabular}{|l|}
\hline Key w o r d s \\
Agriculture, \\
$\begin{array}{l}\text { Demand, Fisheries, } \\
\text { Nutrition, } \\
\text { Production }\end{array}$ \\
\hline Article Info \\
\hline $\begin{array}{l}\text { Accepted: } \\
\text { 07 October } 2020 \\
\text { Available Online: } \\
\text { 10 November } 2020\end{array}$ \\
\hline
\end{tabular}

\section{Introduction}

Assam is a state of north-east India which is situated along Brahmaputra and Barak valley. As per the 2011 census, The Assam covers a total of 78,438 sq. $\mathrm{Km}$ of the geographical area. Due to heavy rain, flood in Assam is a major natural disaster. The main river, the Brahmaputra and its tributaries caused the flood to nearby areas and created an excessive economic loss to the people. The river Brahmaputra enters Assam on the north-west of Sadiya and flows about $740 \mathrm{~km}$ through the heart of the Assam and finally enters Bangladesh (Ayyappan et al., 2017).
In India, fish and shellfish production in 2017-18 from capture fisheries and aquaculture being around 12.6 million tons of which the state Assam contributed approximately $2.6 \%$ to the total production of India. There has been a tremendous increase in fish production, from 1.58 lakh tons in 2000-01 to 3.27 lakh tons in 2017-18. The state has shown a 2.06 times increase in fish production from 2000 to 2018 but couldn't satisfy the consumer demand for fish and imported 11,357 tons of fish from other states. A 3.05 times increase in fish seed production from 2000 to 2014 has been noticed. The state has abundant eries resources in terms of ponds and tanks, derelict water body, reservoir, forest fisheries, river fisheries which occupy 73065, 86204, 1713, 4835, 167095 hectors of total area respectively. The optimal utilization of these available water resources and the adoption of scientific techniques can increase fish production tremendously. Assisting farmers and spreading awareness can further boost fish production.

Numbers of rivers from the northern and southern side of Assam join the Brahmaputra and develop numbers of flood plain wetlands which create feeding and breeding ground for indigenous fish fauna. There is a lack of the optimum utilization of these natural ecosystems for both commercial and indigenous fish production.

Several researchers studied the different ecosystems of India, which gives an overview of the aquatic resources of the country. Vijaylaxmi and Vijaykumar (2011), documented 29 numbers of freshwater fish species from the Bheema River in Gulbarga 
district of Karnataka. Sonawane and Barve (2015), has also carried out a similar type of study in Kasura dam of Maharashtra and documented 20 numbers of fish species of belonging to 7 orders and nine families. In Assam, some of the significant contributions to such area-specific studies were made by (Kalita and Deka, 2013; Goswami and Zade, 2015; Chutia et al., 2018). Most of these contributions have been based on fish production, region-wise genetic diversity and their conservation. Many researchers documented work in the field of ichthyology and their importance in terms of biodiversity in the aquatic environment (Ashashree et al., 2008; Shinde et al., 2009 and Brinda et al., 2010; Sarwade et al., 2010).

This article deals with the present scenario on fish production, available resources and opportunities to boost fish production of Assam. So, this study has the objective to help the fishery officers and fishery extension workers to choose the resource-based best management criteria to enhance the fish production of the state.

\section{Fisheries resources of Assam}

Assam has abundant fisheries resources which include both utilized and unutilized resources. Beels are the most prominent fisheries resource in Assam which harbors maximum numbers of indigenous fish fauna. These are commonly found along with the river Brahmaputra, Ganga, and Barak basin, especially along their middle and lower stretches in the eastern and north-eastern parts of India (Ayyappan et al., 2017). There are 1197 and 416240 numbers of registered beel fisheries and ponds and tanks in Assam which covers 100815 hectors and 73065 hector geographical areas respectively.

The Nagaon and Chachar district has the highest number and area of ponds and tanks respectively. With the addition to that, Assam has an attractive river and forest fishery which covers 167095 hectors and 4835 hector area, respectively (ANON, 2018b). Other forms of resources like Swamps or derelict water bodies include 86204 hector which are the wetlands formed mainly due to eutrophication accelerated by a natural and artificial process like organic enrichment, disposal of waste, etc. They represent the transitional stage between the semi-aquatic and terrestrial ecosystem (ANON, 2018b; Ayyappan et al., 2017) they are the most productive ecosystem on the Earth (Fig. 1, Table 1 and 2).

Production of fish and shellfish species mostly depends upon the resource availability and how efficiently to utilize the food source. Nagaon district produced the highest quantity of fish, followed by Cachar. The maximum quantity of fish was imported to the Kamrup district in the year 2017-18. There are 263 numbers of the registered raw fish market and two dry fish market in Assam, which supplies the fishes to the whole state (ANON, 2018b).

Though carp culture is the main component of aquaculture (Thomas et al., 2003), some other species also gaining importance, some region of Assam is also engaged with the breeding and culture of air-breathing fishes such as magur, singhi, koi (Anabas testudineus), etc. Progressive fish farmer of Baska district under Bodoland Territorial Autonomous Districts has also initiated cuchia farming along with integrated pig cum fish farming unit, integrated fish cum horticulture unit, seed raising unit, composite fish farming unit.

\section{The ornamental fishery of Assam}

The Ornamental fishes are one of the essential components of fisheries that provide aesthetic beauty and upkeep of the environment. These are colourful, attractive fishes having some specific colour patterns. Ornamental fishes 
are mainly kept in the aquarium, which has become a significant income source for many people's (Chetia et al., 2018). In India, the Western Ghats and the north-eastern region are considered as the hotspot for indigenous ornamental fishes (Ayyappan et al., 2017). In the north-eastern area, there are 274 fish species have been recorded, out of which 250 species have ornamental value (Mahapatra et al., 2004). Two hundred seventeen fish species have been recorded in Assam, of which 150 has excellent ornamental value (Bhattacharjya et al., 2003).

Numbers of researchers engaged in studying the ichthyofaunal diversity of many regions. A total of 28 fish species with 17 families and 24 genera has been recorded from North Guwahati, of which 16 species were categorized having "excellent ornamental value" and nine species falls under "high ornamental fish" (Rahman et al., 2014). A total of 44 fish species has been recorded from Jiadhal/Kumotiya river of Dhemaji district of Assam belonging to 9 orders (Cypriniformes, Cyprinidontiformes, Beloniformes, Siluriformes, Synbranchiformes, Osteoglossiformes, Perciformes, Tetradontoformes and Clupeiformes), 20 families and 28 genera and the majority of ornamental fishes were belonging to order Cypriniformes (Chetia et al., 2018). From Majuli island, a total of 62 numbers of ornamental fish species has found that belonging to 9 orders, 22 families and 42 genera and the majority of fish species represented by the family Cyprinidae (20 species) followed by Bagridae (5 species), Belontidae and Channidae (4 species each) (Kumar and Sabitry, 2012).

Major carps, Intermediate group fishes and small group fishes recorded in the Brahmaputra valley in the range of 17, 20 and 44 species (Goswami and Zade, 2015). There are 78 numbers of registered commercial units dealing with ornamental fishes, of which Kamrup district has maximum (10 nos.) numbers of the ornamental fish unit (ANON, 2018b).

\section{Fish seed production in Assam}

The growth of the fish depends on the quality of fish seeds. In Assam generally, the time sequence of induced breeding for silver carp and grass carp during April, followed by catla, rohu, and mrigal, although there is no hard and fast rule (ANON, 2017). Chinese circular hatchery, AAU model carp hatchery, portable carp hatchery, breeding hapa, mini bundh, etc. are popular technologies adopted by the farmers to produce good quality seeds. There are 500 private and 21 government hatcheries in Assam, which produced 7997.45 million fries from private hatcheries and 2.68 million fries from government hatcheries in 2017-18 (ANON, 2018b). Nagaon and Kamrup district has a maximum number of private and government hatcheries, respectively (Fig. 2).

A total of 23 registered ornamental fish production units in Assam, out of which only one comes under government. During 2017$18,2.5$ to 3 lakh nos. of ornamental fish has been exported outside the state which worth 10 lakh rupees (ANON, 2018b). The exported ornamental fish species are Botia, Chital, Chanda, Colisa, Puntius, Channa, etc.

The state is also famous for the seed production of magur. Nalbari district has now become a destination for magur seeds as farmers from different regions of Assam like Bongaigaon, Jorhat, Sivasagar, Lakhimpur, Kamrup, Darrang, Sonitpur, etc. procuring magur seed from Nalbari. Departmental farm in Guwahati (Ulubari fish Seed Farm) has successfully breed Puntiussarana (Cheniputhi) in the year 2014 that is a success of the fisheries sector of the state. 
Table.1 Fisheries resources of Assam

\begin{tabular}{|l|l|l|l|l|}
\hline Resources & Numbers & Area (in hector) \\
\cline { 2 - 5 } & $\begin{array}{l}\text { Total } \\
\text { number }\end{array}$ & $\begin{array}{l}\text { Dist. Occupying } \\
\text { highest numbers }\end{array}$ & Total area & $\begin{array}{l}\text { Dist. Occupying } \\
\text { maximum areas }\end{array}$ \\
\hline Registered beels & 1197 & Dhubri & 100815 & Nagaon \\
\hline Ponds and tanks & 416240 & Nagaon & 73065 & Cachar \\
\hline River fisheries & 622 & Sivasagar & 167095 & Dhubri \\
\hline Forest fisheries & 239 & Cachar & 4835 & Golaghat \\
\hline Derelict water body & 5524 & Dhubri & 86204 & Nagaon \\
\hline Reservoir fisheries & 1 & Dima-Hasao & 1713 & Dima-Hasao \\
\hline
\end{tabular}

Source: ANON (2018b)

Table.2 List of district wise fish and fish seed production of Assam, 2017-2018

\begin{tabular}{|c|c|c|}
\hline Districts & $\begin{array}{l}\text { Fish Production (in } \\
\text { tons) }\end{array}$ & $\begin{array}{l}\text { Total Fish seed production (in } \\
\text { a million fry) }\end{array}$ \\
\hline Kokrajhar & 6438 & 0.00 \\
\hline Dhubri & 19104 & 6.80 \\
\hline Goalpara & 8485 & 98.00 \\
\hline Barpeta & 19762 & 4223.00 \\
\hline Morigaon & 21472 & 765.60 \\
\hline Nagaon & 40647 & 1120.00 \\
\hline Sonitpur & 11813 & 45.00 \\
\hline Lakhimpur & 12789 & 8.83 \\
\hline Dhemaji & 5088 & 10.15 \\
\hline Tinsukia & 13818 & 12.00 \\
\hline Dibrugarh & 11125 & 5.12 \\
\hline Sivasagar & 16479 & 15.77 \\
\hline Jorhat & 12626 & 2.22 \\
\hline Golaghat & 8074 & 8.00 \\
\hline Karbi-Anglong & 491 & 0.00 \\
\hline Dima- Hasao & 142 & 0.00 \\
\hline Cachar & 31030 & 80.00 \\
\hline Karimganj & 13895 & 1472.00 \\
\hline Hailakandi & 11364 & 20.00 \\
\hline Bongaigaon & 7899 & 5.00 \\
\hline Chirang & 1383 & 7.00 \\
\hline Kamrup & 20922 & 24.14 \\
\hline Nalbari & 13206 & 15.50 \\
\hline Baksa & 6766 & 25.00 \\
\hline Darrang & 10344 & 29.00 \\
\hline Udalguri & 2100 & 2.00 \\
\hline Total: & 327262 & 8000.13 \\
\hline
\end{tabular}

Source: ANON (2018b) 
Fig.1 Trend of total fish production of Assam and India

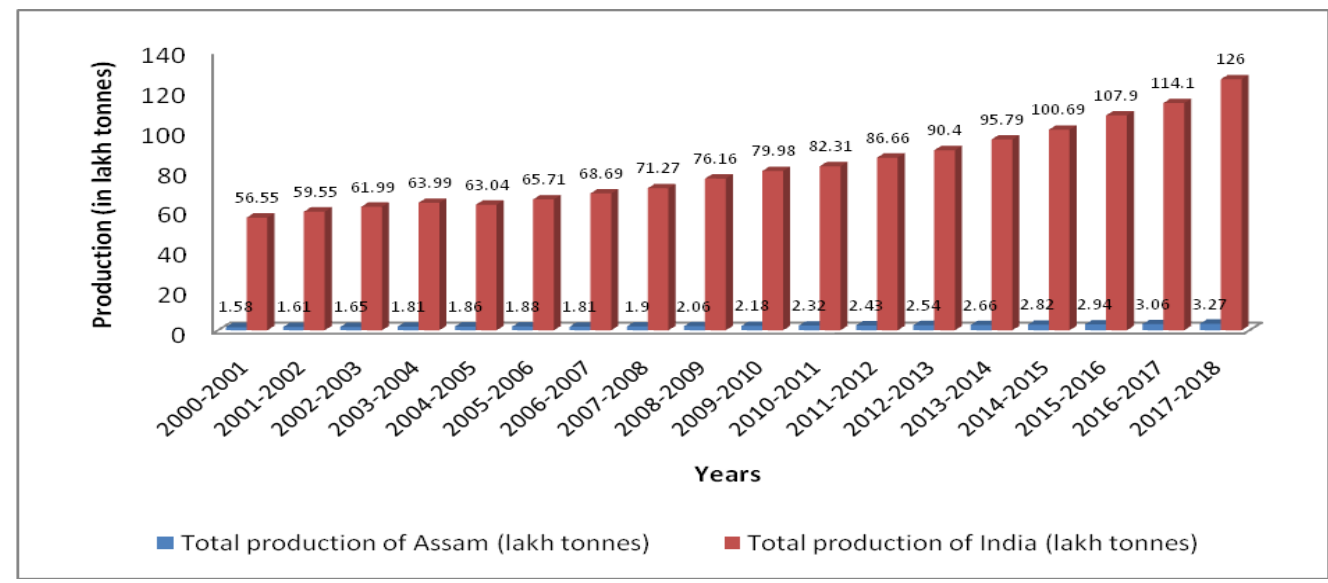

Source: ANON (2019), ANON (2018a), ANON (2018b)

Fig.2 Graphical representation of seed production of India and Assam

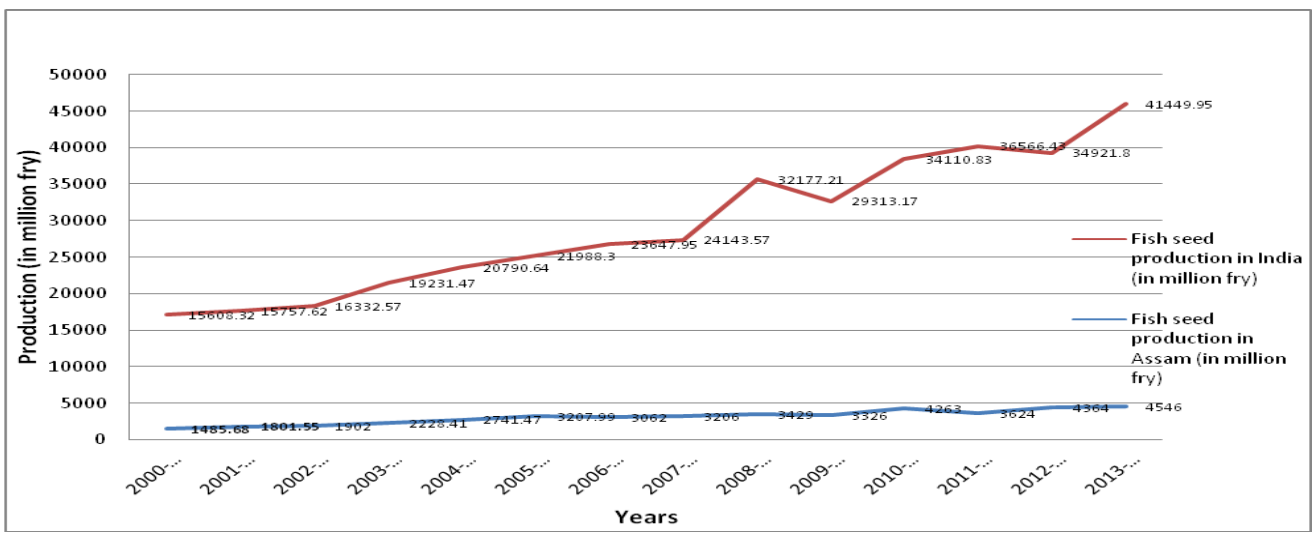

Source: (ANON, 2018a)

\section{Dry fish market of Assam}

Fish drying is known to be the oldest method of preservation of animal protein. With the development of food preservation and processing technology, several new products from dry fish have been introduced. Traditional dry fish products such as fermented fish (mainly Puntius species), dried fish (Numsing), hukoti, salted fish (Puntius sophore, Colisa spp, etc.), are most popular in Assam. Fish drying is considered the least expensive method of food preservation and as a flavouring agent in other food items (Purkait et al., 2018). Several techniques such as sun drying (solar tent drier, drying racks), mechanical drying (cabinet drier, kiln drier, tunnel drier, spray drier, drum drier) have popularly been used. In India, $32 \%$ of the total marine catches used for producing dry fish (Aziz et al., 2019). North-East India has the maximum number of dry fish consumers, and the "Jagiroad dry fish market" (Largest dry fish market of Asia) at Morigaon district acts as the gateway of fry fish for entire North-Eastern region. This market is the primary income-generating source for several neighbouring stakeholders and involves a large number of peoples for drying, grading, assembling, packaging, storing, transportation, etc. 


\section{Fishing gears used in Assam}

A diverse range of fishing gears is used in different water bodies for catching fish. Catching of fish depends on the selection of gear, and it differs from one water body to others (Islam et al., 2013). For complete harvesting of fish from the pond, drag nets are mainly used. Lift net, cast net, hook and line are also used in the pond. During flood dip net, gill net (Langijal), cast net, spear, polo, etc. are the major gears to catch fish. Smaller fishes, frogs, insects, earthworms, artificial baits made up of rice bran or wheat flour, etc. are used as bait for hook and line fishing (Chakravartty and Sharma, 2013). This fishing method in the river is considered a hobby for many people (Gurumayum and Choudhury, 2009). Different types of traps made up of bamboo such as polo, sepa, jakoi, juluki, ghani, dingora, etc. and some scooping gears like jakoi, pahjal, dhekijal, etc. are also popular. Katal fishing is the unique indigenous fishing technique which is also known as 'Jeng fishing' in some regions (Chakravartty and Sharma, 2013).

From the above discussion it can be noticed that in spite of having sufficient fisheries resources, the fish produced from Assam is not enough to satisfy the demand. Public demand for fish can be satisfied by adopting non-conventional aquaculture techniques and proper utilization and management of available resources (Gogoi et al., 2015). There is an excellent scope to produce more fish by adequate control of beels (Baruah et $a l ., 2000)$. The productivity from beel can be enhanced through a culture based capture fisheries with community participation. Cage and pen culture can be done based on the water depth and can also use some fish aggregation devices to attract indigenous fishes from wild (in-situ conservation) in case of open beel.
Biodiversity can be a vital component in the economic valuation of the beels. The economic value of biodiversity has not been studied yet (Baruah et al., 2000). The relationship between changes in biodiversity and changes in the primary productivity of the beels is required to establish for implementation of appropriate conservation techniques.

\section{References}

ANON, 2017. Package of practices on Fisheries and Aquaculture. Directorate of Fisheries, Govt. of Assam. 20.

ANON, 2018a. Handbook of fisheries statistics. Department of Animal Husbandry, Dairying and Fisheries, Ministry of Agriculture, Government of India.

ANON, 2018b. Statistical Handbook-Assam. Directorate of Economics and Statistics, Govt of Assam. pp. 105118.

ANON, 2019. Annual report 2018-19. Department Of Animal Husbandry, Dairying and Fisheries, Govt. of India. 5.

Ashashree H M., Venkateshwarlu M and ReneukaSwamy H M. 2008. Diveristy of fish fauna in Nagathibelagulu pond, Shimoga, Karnataka. Advances in aquatic ecology. 2, 95-97.

Ayyappan, S., Moza, U., Gopalakrishnan, A., Meenakumari, B., Jena, J.K. and Pandey, A.K. 2017. Handbook of fisheries and aquaculture. Directorate of Knowledge Management in Agriculture, Indian Council of Agricultural Research.p.172, 276-281.

Aziz, A., Sahu, S., Das, B. K., Dora, K. C., Chowdhury, S., Hazra, S. and Sahu, S. 2019. The efficiency comparison of marketing channels at Jagiroad dry fish market, Assam during 20172018.Journal of Entomology and 
Zoology Studies.7 (5): 1273-1275.

Baruah, U.K., Bhagowati, A.K., Talukdar, R.K. and Saharia, P.K.2000.Beel Fisheries of Assam: Community-based Co-management Imperative. Socscience. 23, 36-41.

Bhattacharjya, B.K., Choudhury, M. and Sugunan, V.V. 2003.Ichthyofaunistic resources of Assam with a note on their sustainable utilization, in Proceedings of the Workshop on Participatory Approach for Fish Biodiversity Conservation in Northeast India. National Bureau of Fish Genetics, Lucknow, India. p. 85105.

Brinda, S., Srinivasan, M. and Balakrishnan, S. 2010. Studies on Diversity of Fin Fish Larvae in Vellar Estuary, Southeast Coast of India. World J. Fish and Marine Sci. 2(1): 44-50.

Chakravartty, P., and Sharma, D.S. 2013. Different types of fishing gears used by the fishermen in Nalbari district of Assam. Interdisciplinary Research. 2, 177-191.

Chetia, D., Parvin, B. R. and Borah, S. 2018. Ornamental Fish Diversity in the Jiadhal/Kumotiya River of Dhemaji District，Assam，India. Int. J. Curr. Microbiol. App. Sci. 7(10): 33943398

Chutia, S. J., Yashwanth, B. S., Baruah, A. K., Kashyap, A., Chetia, B. R., Nath, B. B. and Chripsin, C. L. 2018. Trends in fish production of Assam: An analysis. International Journal of Current Microbiology and Applied Sciences. 7(11): 3417-3422.

Gogoi, B., Kachari, A., Dutta, R., Darshan, A. and Narayan, D. 2015. Fishery based livelihood approaches and management of fishery resources in Assam, India. Forest. 5(501): 2-514.

Goswami, C., and Zade, V. S. 2015.Ornamental fish Diversity across $\begin{array}{lll}\text { Brahmaputra } & \text { Valley } & \text { of } \\ \text { Assam. International } & \text { Journal } & \text { of }\end{array}$ Innovative Science, Engineering and Technology. 2(1): 547-549.

Gurumayum, S.D., and Choudhury, M. 2009. Fishing methods in the rivers of Northeast India. Indian Journal of Traditional Knowledge.8 (2): $237-$ 241.

Islam, M. R., Das, B., Baruah, D., Biswas, S. P. and Gupta, A. 2013. Fish diversity and fishing gears used in the Kulsi River of Assam, India. Annals of Biological Research. 4(1): 289-293.

Kalita, T., and Deka, K. 2013. Ornamental fish conservation in the flood plain wetlands of lower Brahmaputra basin. Advances in Applied Science Research. 4(5): 99-106.

Kumar, D. M., and Sabitry, B. 2012. Diversity of ornamental fishes in the river island Majuli, Assam. Global Journal of Bio-Science and Biotechnology. 1(1): 81-84.

Mahapatra, B. K., Vinod, K. and Mandal, B. K. 2004.Ornamental fish of North Eastern India-Its distribution and conservation status. Environment and Ecology. 22(3): 674-683.

Purkait, S., Sahu, S., Arefin, B., Pradhan, S. K., Sharma, A., Boda, S. and Sahu, S. 2018.Economic Analysis of Fish Drying in Junput Khuti of West Bengal. Int. J. Curr. Microbiol. App. Sci. 7(10): 3471-3479.

Rahman, S., Kakati, S., Choudhury, J. K., Sarma, P. C., Barua, E.and Dutta, A. 2014.Ornamental ichthyofaunal diversity of North Guwahati, Assam, India. IOSR Journal of Agriculture and Veterinary Science. 7(4): 10-13.

Sarwade, J. P. and Khillare, Y. K. 2010.Fish diversity of Ujani wetland, Maharashtra, India. The Bioscan. 1, 173-179.

Shinde, S. E., Pathan, T. S., Raut, K. S., 
Bhandare, R. Y. and Sonawane, D. L. 2009c.Fish biodiversity of Pravara River, in Devgad Dist.

Sonawane, D. L., and Barve, M. B. 2015.Ichthyofaunal study of Kasura dam district Jalna (MS) India. The Ecoscan: Special. 8, 319-323.

Thomas, P.C., Rath, S.C. and Mohapatra,
K.D. 2003. Breeding and seed production of finfish and shellfish. Daya publishing house.p.40-41.

Vijaylaxmi, C., and Vijaykumar, K. 2011. Biodiversity of fish fauna of the Bheemariver in Gulbarga district of Karnataka. The Ecoscan. 5(1/2): 2125.

\section{How to cite this article:}

Rajesh Debnath, Gora Shiva Prasad, Abdul Aziz, Kovvuri Chalapathi, Ranga Ram Mohan, Satarupa Ghosh and Abhishek Kumar. 2020. The Present Fisheries Status of Assam: A Review. Int.J.Curr.Microbiol.App.Sci. 9(11): 629-636. doi: https://doi.org/10.20546/ijcmas.2020.911.077 